\title{
The Importance of Implementing a Multimedia Application \\ Created according to the ADDIE Instructional Design Model in Writing and Reading the Letters of the Alphabet
}

Fadil Novalić, Emruš Azizović, Faruk Selimovićand Muzafer Saračević Department of Computer Science, University of Novi Pazar

\section{Abstract}

This paper analyzes the impact of multimedia content on success in learning to write and read the letters of the alphabet. For the research purpose and according to the ADDIE model of instructional design, a multimedia application was created for learning to write and read the letters of the alphabet. This paper describes the application interface display, which presents the functions and the parts of the program code. In the focus of the research are the technical possibilities for the use of multimedia application, as well as the impact of its use on the awareness of pupils and teachers on the importance of the introduction of multimedia teaching content. The main research was focused on the effectiveness of learning to write and read the letters of the alphabet and was carried out by comparing the performance of pupils at the end of the school year in two primary schools.

Keywords: application; e-learning; education; improving learning.

\section{Introduction}

E-learning encompasses any kind of learning with the use of modern technologies. This usually involves the use of computers. The American Association ASTD (American Society for Trainers and Development) defined e-learning as a methodology under which the teaching content or the learning activities are delivered by electronic technology (Glušac, 2012). 
Multimedia is a combination of different content formats, most commonly text, images, sound, animation and video. The literature offers the following definition: "Multimedia is a combination of different media: a combination of text and images (pictures, icons, animations, movies), a combination of text and sound (music, speech) or a combination of text, image and sound" (Sukić, 2008, p. 9).

The pace of technological changes is more obvious, along with a dramatic increase in computer processing, increase of network bandwidth, combination of media and the growth of communication and interactivity, and it is easy to assume that the classrooms have completely changed. The changes are, indeed, underway, but it would still be an exaggeration to say that technology has radically changed the teaching and learning in most educational institutions. The primary relationship between teachers and pupils and the implementation of teaching and learning has been relatively unchanged for hundreds of years.

E-learning using multimedia content is finding its place in today's educational content. This type of e-learning and its impact on pupil achievement has been the subject of many textbooks and scientific papers.

\section{Previous research}

In the original scientific and research paper, the authors (Song et al., 2016), excluding the direct impact of prior knowledge, examined the effects of self-regulation and motivation on the increase of overall students' understanding in a complex multimedia learning environment. The paired sample of t-test shows significant differences in participants' knowledge shown on the pre-test and the post-test: $\mathrm{t}(213)=20: 29, \mathrm{p}<.001, \mathrm{~d}=1.84$ in declarative knowledge; $\mathrm{t}(213)=18.73, \mathrm{p}<.001, \mathrm{~d}=1.56$ in conceptual knowledge.

Multimedia content dominates work with pupils in lower grades of primary school. Many textbooks for pupils in lower grades of primary schools have an accompanying $\mathrm{CD}$ with multimedia content. It is often the case with foreign language textbooks. The role and importance of the application of information technologies in educational work with younger learners is undeniable (Purić \& Maričić, 2012).

Education in modern society requires innovations in teaching. They can be introduced through various aspects of the application of techniques and information technology in the educational process in schools, including multimedia content. The development of telecommunications technology and the massive use of the Internet has enabled interactive distance learning based on systematic approach using electronic multimedia information sources. The pupils are following multimedia presentations more attentively. They memorize better the subject matter and participate more actively in the process of learning new content. Faster acquisition of knowledge allows pupils to think, analyze and make conclusions, to commit more to learning through research, by discovering and solving problems. In addition to formal education, pupils can also receive nonformal education using computers at home (Ostojin, 2012). 
In their paper, the authors (Lauc et al., 2014) used a VARK sensory model: Visual, Aural, Read/Write and Kinesthetic, which refers to the sensory modality of the individual. According to the results of the VARK questionnaire, two out of three pupils have multi-modal sensory preferences and prefer to combine different types of multimedia resources.

In their study on the positive impact of virtual environments on learning, the authors (Korićanin et al., 2014) point out that the most common virtual environment is the one that is based on multimedia. They state the fact that $55 \%$ of the pupils have had experience with video games, $27.5 \%$ with virtual worlds, $12.5 \%$ with the virtual classroom, while $5 \%$ of them have had experience with virtual laboratory.

There are many reasons in favor of the use of multimedia in teaching, of which the two most important are:

1. the possibility of presenting the material in a very interesting way, sometimes even through a game;

2. a picturesque presentation of certain elements of the material to the children through image, audio and video content, and interaction with multimedia educational software.

An important feature of the development of e-learning is integration of learning systems into the multimedia systems. By including multimedia systems, the quality and the effect of the use of electronic educational materials have increased. The most important result of the multimedia is the ability to achieve real interactivity which proved to be a key factor in the quality and efficient use of electronic content in the educational process (Sukić, 2008, p. 77).

If we analyze learning in the context of collection and processing of information directed towards different senses (sight, hearing, touch, etc.), we can conclude that the benefits of information technology to the learning process are numerous, since they offer numerous possibilities of exchanging information in various formats (text, sound, video) (LINKgroup, 2012).

Some professional papers researched the attitudes of teachers on the implementation of information technology in the educational process of pupils in lower grades of primary school. The survey on the opinions of teachers on the importance of information technology and the elements that enable its implementation in the teaching process has shown that the application of information technology in teaching is significant for the majority of teachers (90.4\%). This opinion is not influenced by differences in terms of seniority and qualifications of the teachers (Purić \& Maričić, 2012).

\section{The importance of multimedia content in the systems for e-learning}

Multimedia content contributes to a new method of teaching and learning in which more attention is directed towards the pupil, not the teaching content or the teacher. 
It can be said that introduction of the multimedia helps achieve the following positive results of the learning process:

1. the educational content becomes more interesting, which leads to greater motivation of the pupils;

2. the theoretical elements can be represented graphically, allowing better intelligibility of the material;

3. tests providing feedback can be integrated in the curricula, which allows pupils to independently check their knowledge and encourages them to compete with themselves, improving their success in every subsequent testing attempt;

4. the learning process is adjusted to individual differences among pupils, which offers every pupil the opportunity to achieve the maximum in the learning process, relying on their own individual characteristics/advantages.

Digital animations are the form of multimedia with great potential. By incorporating 3D graphics and creating the conditions for the user to interact with objects in a way that simulates real-life circumstances, the conditions of virtual reality are created. Virtual reality has a great potential for use in a variety of professional fields, such as architecture, business modeling, urban planning, medicine, aviation and so on. The progress in technology has allowed a more intensive application of virtual reality in education (LINKgroup, 2012).

Multimedia is not unknown to the new generation of pupils. The pupils of the 21st century are different from the previous generations in their different way of life and work. Every day they are surrounded by multimedia; the information flow is faster than before so children nowadays are informed better than before. They search for information and use them on a daily basis. Pupils make effective use of a computer, a mobile phone, a DVD and other multimedia. Therefore, their needs go beyond the level of traditional teaching (Šikl, 2011).

The use of multimedia in teaching has its theoretical background based on pupils abilities to better memorise the material that has visual effects. Recent learning theories discuss the conditionality of the learning process through visual perception and people's various cognitive abilities (LINKgroup, 2012). In essence, the amount of permanently memorised information depends on the intensity of engagement of the senses during learning. It has been scientifically proven that pupils with average abilities can remember $10 \%$ of the reading content, $20 \%$ of the content they have heard, $30 \%$ of the content they have seen, $50 \%$ of the content they have both seen and heard, $70 \%$ of what they can dramatize and write themselves, and even $90 \%$ of the content they themselves can say, implement, and do (Šikl, 2011). In his book, the author (Mayer, 2009) states: What is the role of a learning theory in multimedia teaching content design? Decisions on how to design multimedia content are always made based on a concept under which people learn - even when the underlying learning theory is not stated. Designing multimedia teaching content always requires that content designer is informed on 
how human mind works. For instance, when in a multimedia presentation the screen is saturated with colourful words and images written, which are flashing and moving about, it reflects the designer's concept of human learning.

Multimedia content can be viewed on computers, tablets and mobile devices using various software. Web browsers belong to such software as well, enabling online use of multimedia in teaching. The use of multimedia by using ICT is facilitated by formatting standards and multimedia data compression. They, among other things, address the quality, size and portability of the multimedia files. The most commonly used standards for image are JPEG, for audio MPEG-1 Layer III (MP3) and for video MPEG-2 and MPEG-4.

In all this, the children should be enabled to use information technology to master basic skills, such as reading and writing the letters (the alphabet). The availability of online e-lessons for learning how to write and read the letters of the alphabet justifies this view. These lessons make the learning interesting, even turn it into a kind of game, which increases the motivation to learn. The author (Glušac, 2012) states in her book: "The children experience the computer as a toy, as a source of entertainment, and are ready at any moment to replace the classic work during the lesson with work on the computer. At the same time, by offering them educational content designed in the form of games we meet the teaching objectives in a much quicker period and with better pupil achievement. Motivation is significantly higher and pursuant to all this, and the teaching process improves and becomes more efficient" (p. 30).

Given the already existing application of multimedia content in teaching students in lower grades of primary school and pupils tendency towards computer usage, we thought it important to examine the impact of multimedia applications on the success of first-graders in learning to read and write the letters (the alphabet). We have created such an application and tested its actual usage during the school year. Compared to other applications for learning to read and write the letters of the alphabet which can be found on the Internet, our application is complemented by animations of letter writing, which makes it even more complete. We have investigated whether the use of applications has led to a change in the attitudes of pupils and teachers towards the use of the multimedia in teaching. In our study, we have included first-graders of another primary school, in which they did not use multimedia content in learning the alphabet. We have collected the grades with which the teachers assessed pupils achievement in reading and writing letters in both schools at the end of the school year and made a comparison of their success.

\section{Multimedia application for learning the alphabet}

It is essential that pupils master the alphabet, i.e. reading and writing the letters, at the very start of the school, as quickly as possible. In order to achieve this objective and for the purpose of learning to read and write letters, we have created a multimedia application that will improve the efficiency of mastering this teaching content. For the 
age at which children start learning the alphabet, the learning efficiency is better if the material is made interesting. In e-education, teaching materials may be presented in the form of games or animations. We should pay attention to the pedagogical and the psychological characteristics of the e-materials.

\section{Psychological and pedagogical basis for creating the application}

The psychological aspects which should be taken into account when teaching reading and writing the letters of the alphabet, in terms of the pupils' age, are independence in learning and motivation.

The desire for autonomy in learning is determined by pupils personalities and the type of material. There are pupils who easily learn on their own and rarely seek the help of adults, while others more or less seek the adults' help. In our example, the material requires the teachers' or parents' guidance of the pupils through the learning content. The application we created contains the following elements, which can substitute the teachers' help:

1. presentation of all the letters,

2. pronunciation of the letters,

3. pronunciation of words that represent the names of objects in the pictures next to the letters,

4. graphemes of the letters.

These elements give the application an attribute of comprehensiveness. The motivation is influenced by several factors, but the key ones are:

1. to make the material interesting,

2. to reduce the complexity of the teaching materials,

3. to enable pupils' self-testing with feedback,

4. to enable pupils' relearning and improvement on the test results,

5. competition with peers in something that is interesting to everybody.

Our application was created in accordance with the aforementioned factors. It includes graphics, animation and sound, which can be very interesting to the children for whom it is intended, taking into account their age. The application is simple to use. The content appears on the display, and the buttons that pupils are supposed to use are illustrated with pictures that clearly indicate their function. Pupils can test themselves by recognizing the letters and reading the words, and right then they can hear the pronunciation of the letters and the words contained in the application, thus checking the accuracy of their pronunciation. In addition, they can always return to viewing the letters in the application and listen to the pronunciation in order to strengthen their knowledge, and then to retest themselves. Additional motivation for the pupils at that age is participation in each other's conversations over the software used and the success they achieved in its use. It is similar to their competition in reaching a level of a computer game everyone plays. 
The pedagogical aspects of learning to read and write the letters of the alphabet include the place, the time and the learning pace. These are the aspects considered by most e-courses. The pedagogical aspects of e-learning relate to the flexibility of time and place of attendance. In e-learning it is not necessary that all the pupils in the educational process are at the same place at the same time (Saračević et al., 2012). The application for learning letters can be initiated on digital devices, online or without the Internet connection, at a time that suits the pupil. Pupils can choose the learning pace that suits them, and an additional benefit is that it is used on a computer, in an environment which the pupils are used to and in which they feel comfortable.

\section{The development of the application according to the ADDIE model of instructional design}

Instructional design is a process where the learning and the pedagogical theory are applied, as well as various principles and teaching techniques and methods, in order to plan and create learning materials more efficiently and thus shape the process of teaching and learning in specific subjects and lessons (Anđelić, 2008). It connects the theory and practice in the educational process. It represents a methodological framework for finding out how to integrate innovations in practice most effectively.

Recently, the educational technologies are changing the teaching methods, particularly in higher education, and instructional design has become more popular even in programs that take place in a traditional classroom. A typical instructional design process involves several steps: planning, design, production, implementation, evaluation, revision.

The very concept of instructional design is understood differently, but basically it refers to the process by which teaching is planned, designed, built and developed; by which learning is performed, organized and controlled; and solutions, optimal strategies, routes or modes of work and learning are identified. The selected media, modeling and design of the educational content on a macro-didactic plan should help pupils to properly acquire in an easy, interesting and cost-effective manner during the teaching, learning and work process a newly created knowledge which is durable and applicable in every situation.

Instructional design involves the decisions on:

1. how to best distribute the content;

2. how to present information in a way that will provide the most effective learning;

3. how to design and evaluate the activities through which pupils will develop a deeper understanding of the content (use of the information presented, application of concepts and principles;

4. how to design and evaluate the activities through which pupils develop specific skills related to their field of study or work.

For the purpose of our study, an electronic course on learning to read and write letters (i.e., the alphabet) in the form of multimedia application was developed according 
to the ADDIE model of instructional design. This model is developed through five stages: Analysis, Design, Development, Implementation and Evaluation.

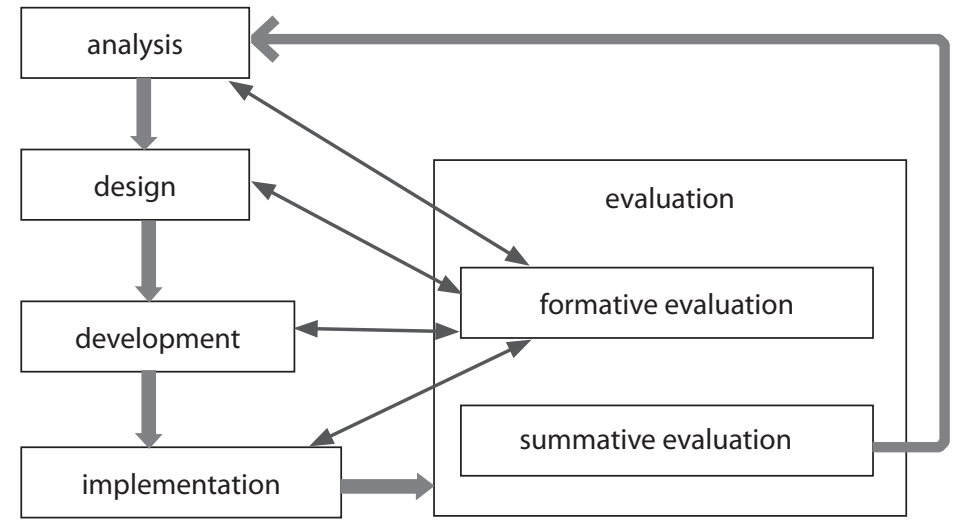

Figure 1. ADDIE model of instructional design

\section{Analysis}

Analysis of the needs and problem identification: The main problem with learning to read and write the letters of the alphabet is that this is the first task that pupils encounter when they start school, and is therefore difficult and requires constant help in learning. In the multimedia application, with the help of animation and sound, learning is more interesting and the application gives pupils instructions instead of the teacher.

Analysis of the tasks and the working conditions: The task of the e-course is to provide a hybrid type of instruction, in which the teacher, in addition to the traditional manner of delivering lectures, also uses multimedia courses that would allow pupils additional independent work at home.

Analysis of the organizational and technical requirements for the realization of the course: Classes take place in a computer classroom. In the primary school where the use of the multimedia application was tested, there is no such classroom. There are computers equipped with the necessary software, and there is a video projector.

Target group: The course was designed for the pupils in the first grade of primary school in Serbia.

Moderator of the course, supervisor: The moderator of the course, as well as the supervisor, is the teacher, who conducts assessment as well.

Implementation period: The teaching content of the e-course was implemented within the educational process in the school year 2018/2019.

Objectives and anticipated outcomes: The course objectives are:

1. primary goal - for the pupils to successfully master reading and writing the letters (the alphabet);

2. secondary goal - to raise the level of pupils' independence in learning and awareness of the usefulness of multimedia applications in learning. 
3. After completion of the course, it is anticipated that the pupils will:

4. know how to read and write all the letters of their mother tongue,

5. be able to learn independently with the help of computers,

6. be ready to independently find new educational applications and games.

\section{Design}

I. Overview of the topics

All the topics within the e-course relate to the lesson about learning letters (the alphabet), in the Mother tongue subject.

II. The scope of the project

The course covers most of the teaching materials, since the modules on learning letters make up the main part of the curriculum of the Mother tongue subject for the first grade.

Purpose: The activities are designed to represent an upgrade of the teacher's lecture during the class.

Control Point: The last class of the school year in which the teachers assess children's success in learning to read and write the letters (the alphabet).

III. The materials (resources)

The teaching material used to create an e-course was the school textbook. Additional materials were audio recordings of the pronunciation of letters and words.

The e-material for this course was made in the form of Adobe Flash animation. Pupils can view it on their PCs from removable memories (USB flash drive, CD, etc.), and on the Internet, on a web page.

IV. The tasks of the course

Teaching tasks are essential elements of teaching determined by the curriculum and are implemented through teaching activities. The curricula are determined in order to contribute to the realization of the tasks.

The teaching process accomplishes three teaching tasks: educational, functional and pedagogical task (Selimović \& Tomić, 2011, p. 318).

This e-course should achieve the following educational tasks:

1. pupils will learn to recognize all the letters,

2. pupils will be able to write the letters,

3. pupils will be able to read words.

The functional tasks of this e-course are the following:

1. pupils will be able to read texts in their mother tongue,

2. pupils will improve their knowledge and skills in the use of information technology,

3. pupils will strengthen the innovative feature of their personality.

What this e-course needs to achieve within the pupils pedagogical aspect is the following:

1. to encourage pupils to find more efficient solutions in mastering the teaching material,

2. to raise the level of pupils' independence in learning. 


\section{Participants}

A teacher and pupils of all six first grade classes of a selected primary school participated in the implementation of the course. The course was run by the teacher, who was also the moderator and one of the creators of the course. The teacher conducts formative assessment of the pupils as well. The internal evaluation of the work was done by analyzing the success of the pupils. The survey, which was also used for external evaluation, was conducted by the authors of the study.

\section{Connection}

The content and the activities of the course are in line with the Curriculum of the subject Mother tongue for the first grade.

\section{Development}

When creating the application, the psychological and the pedagogical bases mentioned above were followed, as well as the requirements set in the analysis and the design phase.

The application was created in the form of animation, and the software used for its development is Adobe Flash. Flash is a software for creating vector graphic objects and their animation. In one place it gathered all the necessary tools: tools for drawing graphics, tools for animation of these graphics, tools for creating interface elements and interactivity, as well as tools for creating the HTML necessary to display graphics, animations and interface elements, as a Web page in a browser (Ulrich, 2003).

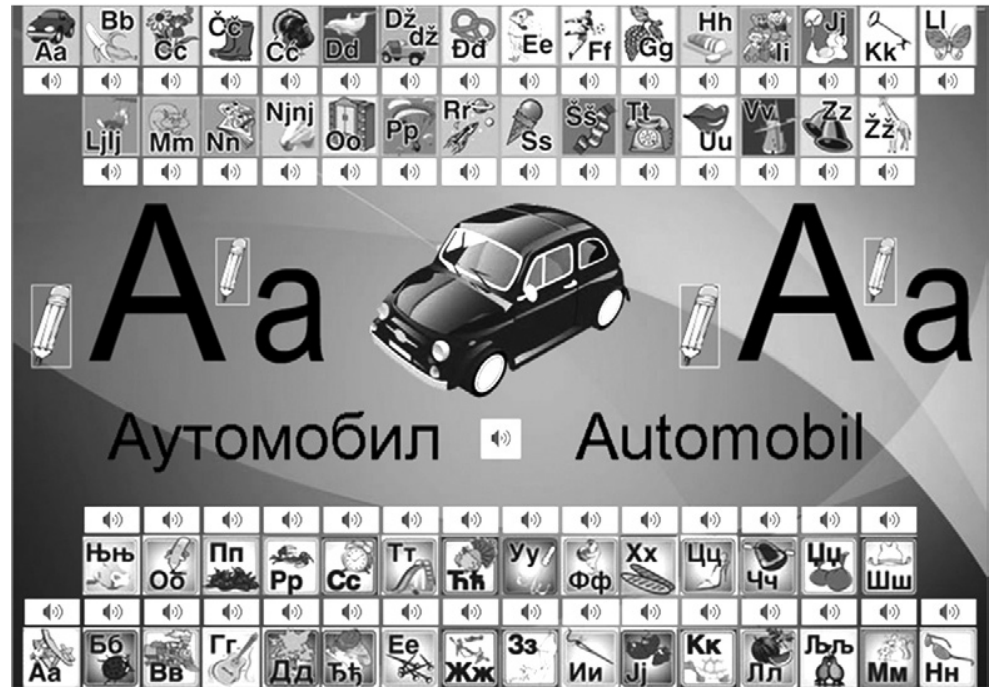

Figure 2. The main animation display for learning letters

The application was designed as a stage displaying all the letters in a form of linked buttons, and individual animations for each letter are retrieved on the stage by clicking the appropriate button. The buttons are presented as thumbnails. Each button shows a block capital letter, both its uppercase and lowercase form, and next to it there is 
an image of an object or being whose name begins in that letter. Such a display is presented in the printed textbook as well. In the animation, next to each button there is an image of a loudspeaker. By clicking on it, the pronunciation of the letter can be heard. The letters in the application are sorted alphabetically. This provides simplicity of the application use.

When the animation is initiated, the display by default loads the external animation, presenting letter A. To load external animations representing other letters on the display, ActionScript 2.0 programming code was used in Adobe Flash:

Source Code 1. ActionScript 2.0 programming code to load external animation onto the display

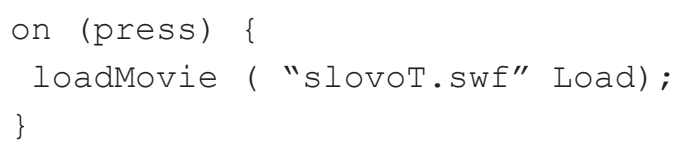

Animation of objects on the display was done using the timeline. Thus, the effect of printing letters was achieved. Each printed letter, both lowercase and uppercase, has its own button with an image of a pencil. By clicking on the pencil, the animation starts and shows how to write the desired letter. In addition to the letters, there are images of objects or beings whose names begin with that letter and the word is provided. The mentioned word presents the name of the object or the being represented by the thumbnail. Among the mentioned inscriptions there is a thumbnail of a loudspeaker. By clicking on it, pronunciation of the word is heard, while by clicking on the image, the sound produced by that object or being is heard.

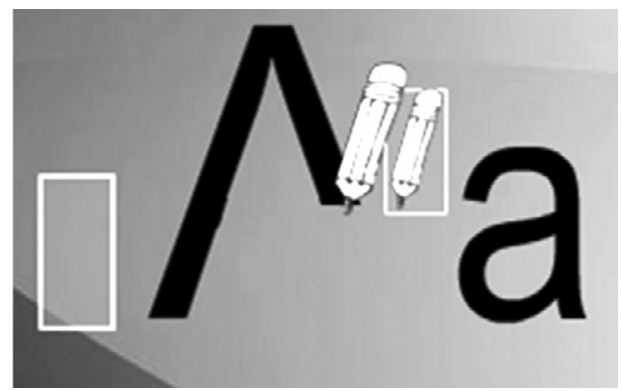

Figure 3. Display of the letter animation

Thus created animation can be done in Adobe Flash Player or any other video player, and can be inserted on the web page as well as used online.

\section{Implementation}

The e-course for learning the alphabet letters was implemented throughout the school year within the Mother tongue subject and during the lessons planned for learning the alphabet letters. Pupils independently used the application at the time and place of their choice, on their own computers, on a CD or on the Internet. 


\section{Evaluation}

In the e-course that is the subject of this work, assessment was done by analyzing the success pupils had achieved in mastering the task of learning to read and write. The evaluation was expanded with a survey to raise the pupils' and teachers's awareness of the possibility of the use of multimedia in teaching. For external evaluation, assessment of the pupils and the survey results were delivered to the school pedagogue and to the author of the study. In joint analysis they came up with new solutions on improving the teaching process and the possibilities of introducing an e-course as a supplement to the traditional teaching process.

\section{Research methodology}

At the beginning of schooling, pupils are is faced with the task which obliges them to read and write in their mother tongue. Learning the letters of the alphabet requires intensive help from teachers in the school and from adults at home. The use of information technology in learning the letters could partially replace the help of the adults. In addition, learning aided by computers can be more interesting to the pupils than working with people, and this would affect the increase in the time pupils spend learning. Here we will present a study on the impact of e-learning on the success pupils achieve in learning to read and write letters based on the use of the multimedia application.

\section{The problem, the subject matter and the importance of the research}

The learning process was carried out by reading, listening and observing. All these three processes are indispensable. The human being is born with the capability to listen and observe, while reading and writing skills have to be learned. Therefore, the institutional education of every person starts by learning the letters of their mother tongue script. The period of one or two years in schools is dedicated to this task, and success in it is not optional, but mandatory. In order to learn the letters, i.e. the alphabet, various means are used: picture books, printed books, toys and electronic materials on a computer or the Internet. This brings us to the problem of the research: whether the use of multimedia electronic materials can statistically significantly improve pupils' success in learning to read and write the letters of the alphabet in comparison with the success achieved by using only printed school textbooks. The problem is relevant, given that reading is an essential step at the start of the educational process.

The pupils' interest to use multimedia applications for learning and the relationship between success and the modes of learning - traditional or e-learning were the focus of interest.

Learning aided by computer has its advantages and disadvantages. Many people are worried about a great amount of time children spend on the computer. The introduction of e-learning could be significant because children would use the time they spend 
working on a computer for learning. In addition, e-learning has some advantages regarding efficient learning. This study is significant since it points out the benefits of using e-learning materials that are interesting for younger pupils.

\section{Research aims and tasks}

The study aims to determine whether the use of multimedia applications in teaching reading and writing the letters of the alphabet can get better results than the traditional learning method, as well as to contribute to the improvements in teaching of the mother tongue for first grade pupils in primary schools by introducing a combination of traditional and e-education. This goal extends to the domains of the psychological effects on the pupils. They should, by making use of the multimedia application, become aware of the use of computers in teaching in an interesting and useful way, in contrast to the dominant use of computer for playing games.

Relying on the research goals mentioned above, the following research tasks were defined:

The main task of the research was to find the best and most successful way to use the multimedia application while learning to read and write the letters of the alphabet.

Specific research tasks were:

1. raise awareness of the use of multimedia in learning among pupils and teachers

2. explore the possibilities of using multimedia in learning among first grade pupils in school and at home.

\section{Hypotheses}

Based on the defined objectives and tasks of the research, the following hypotheses were set:

1. the general hypothesis is: the use of multimedia applications in teaching reading and writing the letters of the alphabet contributes to better achievements of pupils, in a statistically significant degree;

2. the specific hypotheses were:

a) pupils' awareness of the use of multimedia in learning is not high and can be raised by using the multimedia application in learning to read and write the letters of the alphabet;

b) teachers' awareness of the use of multimedia in teaching can be raised using the multimedia application in teaching reading and writing the letters of the alphabet;

c) appropriate technical requirements are met for the use of multimedia application in teaching reading and writing the letters of the alphabet.

\section{The research variables}

The overall success of the implementation of the multimedia application for learning to read and write the letters of the alphabet is reflected in pupils success in mastering the aforementioned task. Therefore, some variables were included in this study. 
The independent variable: the lecturing method.

The dependent variables:

a) successfully mastered task by the pupils at the end of the school year

b) pupils awareness of the use of multimedia in teaching

c) teachers' awareness of the use of multimedia in teaching.

The lecturing method can be traditional and hybrid (a combination of traditional methods of learning and e-education).

The dependent variable, for the purposes of this research, is marked with two degrees of success: satisfactory and unsatisfactory. The variables that determine the awareness level are not scaled; it is sufficient to establish that there is a positive change.

\section{Methods, techniques and research instruments}

The following research methods were used in this research: the method of theoretical analysis, the experimental, the historical and the statistical methods. The analysis of the theoretical basis of e-learning leads to the theoretical assumptions that underpin the research. The experimental method describes the procedure for performing research on the experimental groups. The historical method tested the pupils' and teachers' awareness of the use of multimedia in the classroom before and after the use of our application for learning to read and write the letters of the alphabet. The statistical method was used for processing the results obtained in the research and for testing their statistical significance.

The survey was conducted by interviewing and evaluating the success pupils had achieved. The following research instruments were used: a questionnaire for pupils, a questionnaire for teachers and a scale for evaluating success pupils had achieved in reading and writing the letters of the alphabet.

\section{Population and survey sample}

The population of the research consisted of first grade pupils of primary schools in Novi Pazar. The sample was intentionally chosen and consisted of first grade pupils from two schools - 152 first-graders from one school, and 128 first-graders from the other school.

The sample from the school with a larger number of first-graders was taken as the experimental group that used the multimedia application in teaching (Group 1), while the other group consisted of first-graders from the school where teaching was carried out in the traditional way (Group 2).

\section{Organization and current research}

The research was conducted in the school year 2018/2019. At the beginning of the school year, the questionnaire was used to collect data on the number of first grade pupils who had a computer and the Internet at home, as well as about the possibilities of the use of information technology in teaching at school. 
At the beginning of the school year, the teachers at the school where the multimedia application was used were given a CD with the application or a URL address of the application on the Internet. The classes during which new letters were discussed were held in the school computer laboratory, where the application was presented to the children using a video projector. At the end of the school year, pupils' achievement in reading and writing the letters of the alphabet was assessed by their teachers, with remarks satisfactory or unsatisfactory. The number of positively and negatively evaluated pupils in both groups was submitted to the author of the research.

A survey was conducted at the beginning and at the end of the school year with both pupils and teachers to determine the awareness level of the use of multimedia in the classroom.

\section{Statistical data processing}

Analysis and interpretation of the data encompass the results obtained by the experimental method. The counting measures (number of pupils) and the measures of the relevant relationship (percentages) were calculated. The results obtained by calculation are presented quantitatively. To test the statistical significance of the differences within the presented pupils' success, the t-test was used.

\section{Research results}

The research hypotheses were taken as the starting point of the research results processing. The results will be presented in the order they were collected and processed.

\section{Fulfillment of the technical requirements for the use of multimedia application}

One of the special hypotheses was: appropriate technical requirements are met for the use of multimedia application in teaching reading and writing the letters of the alphabet.

Using a survey questionnaire, we asked the pupils from Group 1 whether they had a computer and the Internet at home. Out of the 152 pupils, 148 pupils had a computer at home (97\%), and 139 of them were connected to the Internet (91\%).

The school in which we conducted the experiment has a computer classroom with Internet connection and a video projector, so that during the lessons the multimedia application can be presented to the pupils. It could be said that the technical requirements for the use of the multimedia application for learning to read and write the letters of the alphabet would have been fully met if the school owned a computer and a video projector to present the application during lessons, and if each pupil had a computer at home. Since there was a small percentage of pupils who did not have a computer at home, we conclude that our hypothesis was not proved, but there is a high percentage of compliance with the required technical conditions for the use of the multimedia application for learning to read and write the letters of the alphabet. 


\section{The level of awareness of pupils about the use of multimedia in learning}

The specific hypothesis that we will prove here is: pupils' level of awareness on the use of multimedia in learning is not high and can be raised using the multimedia application in teaching reading and writing the letters of the alphabet.

The questionnaire contains two questions:

1. Do you play games with sound and animation on a computer or on the Internet?

a) yes

b) no

2. Do you play funny or educational games?
a) only funny games
b) only educational games
c) both.

The survey with the same questionnaire was conducted at the beginning and at the end of the school year. The pupils who had computers at home responded to the questions. The results of the survey were presented in a tabular code list with data from the questionnaire.

Table 1

The code list for data from pupils' gaming questionnaire

\begin{tabular}{|c|c|c|c|c|c|c|}
\hline \multirow{2}{*}{$\begin{array}{l}\text { Identification } \\
\text { of variables }\end{array}$} & \multirow[b]{2}{*}{ Variable } & \multirow{2}{*}{$\begin{array}{c}\text { Type } \\
\text { of variable }\end{array}$} & \multirow{2}{*}{$\begin{array}{c}\text { Scale of } \\
\text { measurement }\end{array}$} & \multirow{2}{*}{$\begin{array}{l}\text { Modalities } \\
\text { variables }\end{array}$} & \multicolumn{2}{|c|}{ Codes } \\
\hline & & & & & $\begin{array}{c}\text { At the } \\
\text { beginning }\end{array}$ & $\begin{array}{l}\text { In the } \\
\text { end }\end{array}$ \\
\hline \multirow{2}{*}{ II } & \multirow{2}{*}{$\begin{array}{l}\text { Playing } \\
\text { games }\end{array}$} & \multirow{2}{*}{ quantitative } & \multirow{2}{*}{ nominal } & yes & 145 & 148 \\
\hline & & & & no & 3 & 0 \\
\hline \multirow{3}{*}{ LP } & \multirow{3}{*}{$\begin{array}{l}\text { Type of } \\
\text { game }\end{array}$} & \multirow{3}{*}{ quantitative } & \multirow{3}{*}{ nominal } & only fun & 119 & 83 \\
\hline & & & & only educational & 4 & 6 \\
\hline & & & & both & 22 & 56 \\
\hline
\end{tabular}

At the beginning of the school year, there were $98 \%$ of pupils who played computer games and only $2 \%$ of pupils who never played games. After using the multimedia application at the end of the school year, all the pupils stated that they played computer games.

Regarding the type of games, at the beginning of the school year 119 pupils said they only played funny games (82 \%), 4 pupils played only educational games (3\%), and 22 pupils played both types of games (15\%). By the end of the school year, after the use of the multimedia application, a large percentage of pupils gave different answers. The number of those who still played just funny games decreased to 83 (57\%), the number of pupils who played only educational games was $6(4 \%)$, while the number of those who played both types of games significantly increased to 56 pupils (39\%).

So, after using the multimedia application for learning to read and write letters, the number of pupils who played only educational computer games increased by $1 \%$, 
while the number of those who played both types of games increased by $24 \%$. This proves our hypothesis that the level of pupils' awareness of the use of multimedia in learning is not high and can be raised using the multimedia application in teaching reading and writing the letters of the alphabet.

\section{The level of teachers' awareness of the use of multimedia in learning}

The following and the last specific hypothesis which we are here to prove is as follows: the level of teachers' awareness of the use of multimedia in the classroom can be raised using the multimedia application in teaching reading and writing the letters of the alphabet.

The questionnaire contains only one question for the teachers:

1. Do you use multimedia computer applications in teaching?
a) never
b) rarely
c) moderately
d) often.

The survey with the same questionnaire was conducted at the beginning and the end of the school year. The study included all six teachers who were teaching firstgraders in the school where the multimedia application for learning to read and write the letters of the alphabet was used. The results of the survey are presented in a tabular code list for data from the questionnaire.

Table 2

The code list for data from a survey on the use of multimedia in teaching for teachers

\begin{tabular}{|c|c|c|c|c|c|c|}
\hline \multirow{2}{*}{$\begin{array}{l}\text { Identification } \\
\text { of variables }\end{array}$} & \multirow[b]{2}{*}{ Variable } & \multirow{2}{*}{$\begin{array}{l}\text { Type of } \\
\text { variable }\end{array}$} & \multirow{2}{*}{$\begin{array}{c}\text { Scale of } \\
\text { measurement }\end{array}$} & \multirow{2}{*}{$\begin{array}{l}\text { Modalities } \\
\text { of variables }\end{array}$} & \multicolumn{2}{|c|}{ Codes } \\
\hline & & & & & $\begin{array}{c}\text { At the } \\
\text { beginning }\end{array}$ & $\begin{array}{l}\text { In the } \\
\text { end }\end{array}$ \\
\hline \multirow{4}{*}{ UMM } & \multirow{4}{*}{$\begin{array}{c}\text { Use of } \\
\text { multimedia }\end{array}$} & \multirow{4}{*}{ quantitative } & \multirow{4}{*}{ nominal } & never & 1 & 0 \\
\hline & & & & rarely & 2 & 1 \\
\hline & & & & moderately & 2 & 3 \\
\hline & & & & often & 1 & 2 \\
\hline
\end{tabular}

From the results of the survey it can be seen that after the use of the multimedia application for learning to read and write the letters of the alphabet, the number of teachers who used multimedia in teaching increased to moderately or often, whereas the number of teachers who never or rarely did so decreased. This proves our hypothesis that the level of teachers' awareness of the use of multimedia in the classroom can be raised using the multimedia application in teaching reading and writing the letters of the alphabet. 


\section{The success of pupils in reading and writing the letters of the alphabet}

Finally, we prove the general hypothesis of the research: the use of multimedia applications in teaching reading and writing the letters of the alphabet contributes to better pupils' achievement to a degree which is statistically significant.

This study was conducted with two groups of pupils. One group used our multimedia application for learning to read and write the letters of the alphabet. Another group learned the letters in the traditional way. At the end of the school year, the teachers submitted data on the number of pupils from both groups who had successfully mastered reading and writing the letters of the alphabet and those who had not. The results will be presented in tables and graphs. The results regarding the statistical significance of the obtained difference will also be presented.

Table 3

Number of pupils and positive rating in learning to read and write the letters of the alphabet

\begin{tabular}{cccccc}
\hline \multicolumn{2}{c}{ Number of pupils } & \multicolumn{2}{c}{ Positive grades in Group 1 } & \multicolumn{2}{c}{ Positive grades in Group 2 } \\
\hline Group 1 & Group 2 & number & percentage & number & percentage \\
\hline 152 & 128 & 148 & $97 \%$ & 114 & $89 \%$ \\
\hline
\end{tabular}

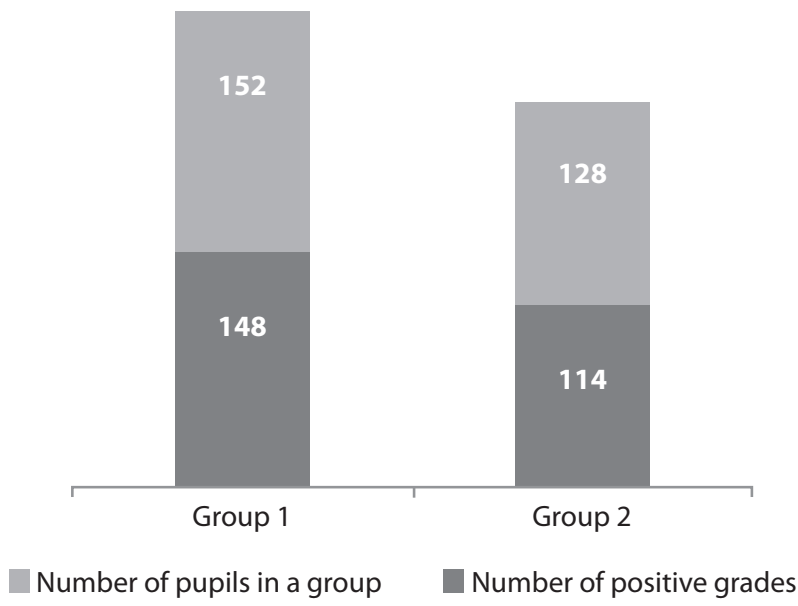

Graph 1. Number of pupils and positive grades in learning to read and write the letters of the alphabet

As we can see in Group 1, 97 \% of the pupils got positive ratings, and in Group 2, $89 \%$ of the students got positive ratings. T-test was used to examine the statistical significance of the obtained differences. Using the formulas for the statistical analysis of data (Kundačina \& Banđur, 2007), we obtained the t-value $t=2.72$. The calculated $\mathrm{t}$-value was compared with the limit values. Based on the statistical tables of limit values, it can be seen that for the sample between 100 and 200 subjects, the limit value of 1.98 is at the level of significance of .05 , and 2.63 at the level of significance of .01 . 
The resulting t-value is greater than the limit value at both levels of significance, which means that the difference of $2 \%$ obtained on the sample was not random. This supports the general hypothesis of our research: the use of multimedia applications in teaching reading and writing the letters of the alphabet contributes to better achievement of the pupils, to a statistically significant extent.

\section{Conclusions}

The use of multimedia teaching content has its own character, which is proved by the existence of a large number of scientific papers on the subject, as well as school textbooks accompanied by discs with multimedia content. In the literature, there is a psychological and pedagogical framework for using multimedia in teaching, the impact of multimedia on learning is assessed as positive, and the current generations of pupils are characterized as the ones who are familiar with information technology.

Given the importance of mastering reading and writing the letters of the alphabet at the beginning of schooling, and taking into account the possibilities of multimedia teaching content, we have created a multimedia application used for learning to read and write the letters of the alphabet. The application was created as animation, with embedded audio. It provides an overview of the Latin and the Cyrillic alphabet used in South Slavic languages, the pronunciation and writing of the letters. It displays items beginning with a specific letter and pronunciation of words represented by images. In the process of creating the application, the psychological and the pedagogical framework of the mentioned teaching material was taken into account, as well as ADDIE model of instructional design. Throughout the five phases of the model, an electronic course on learning to read and write the letters of the alphabet was planned, designed and implemented, based on the use of multimedia application.

Research on the importance of the implementation of the multimedia application created according to the ADDIE model of instructional design in teaching reading and writing the letters of the alphabet was conducted in accordance with methodology that had already been described, and which showed that it was functional in the particular case. Based on the results of the research, we can make the following conclusions:

1. the use of multimedia applications in the classroom for pupils of younger age has a positive effect on pupils' awareness of the purpose of the use of multimedia content on the computer;

2. the impact on teachers was recorded in terms of encouraging pupils to use multimedia in learning, and not only for fun;

3. the use of multimedia in teaching, as well as the general application of information technology, do not need huge, unattainable technical requirements;

4. the use of multimedia applications in the classroom for pupils of younger age enables progress in the adoption of the material. 
The expected and achieved outcomes of the implementation of the multimedia application for teaching reading and writing the letters of the alphabet are:

1. pupils learn new possibilities of the information technology

2. pupils gain a greater degree of autonomy in learning

3. teachers are more engaged in teaching innovations.

Modern school should understand the necessity of innovation in teaching junior grades by use of information technologies, especially with multimedia which can make courses more interesting. This material could be created for a large number of teaching topics and subjects and distributed along the textbooks, which has been done previously, but mainly in learning foreign languages.

\section{References}

Anđelić, S. (2008). Instrukcioni dizajn u e-obrazovanju. XIV konferencija YUINFO 2008. Kopaonik: YUINFO.

Glušac, D. (2012). Elektronsko učenje. Tehnički fakultet „Mihajlo Pupin“.

Korićanin, E., Saračević, M., Biševac, E., \& Kamberović, H. (2014). Concept and types of virtual environments: Research about positive impact on teaching and learning. University Journal of Information Technology and Economics, 1(2), 18-22.

Kundačina, M., \& Banđur, V. (2007). Metodološki praktikum. Merlin company.

Lauc, T., Kišiček, S., \& Bago, P. (2014). Multimedia resources in an online course: Access and usage with respect to sensory modality. Croatian Journal of Education, 16(3), 155-173. https://doi.org/10.15516/cje.v16i0.877

LINKgroup. (2012). E-učenje. LINKgroup.

Mayer, R. E. (2009). Multimedia learning. Cambridge University Press. https://doi.org/10.1017/ CBO9780511811678

Ostojin, O. (2012). Metodički okviri primene informacionih tehnologija u nastavi. In D. Golubović (Ed.), Tehnika i informatika u obrazovanju (pp. 270-275). Univerzitet u Kragujevcu, Tehnički fakultet Čačak.

Purić, D., \& Maričić, S. (2012). Neki aspekti primene informacione tehnologije u nastavi u mlađim razredima osnovne škole. In D. Golubović (Ed.), Tehnika i informatika u obrazovanju (pp. 326-331). Univerzitet u Kragujevcu, Tehnički fakultet Čačak.

Saračević, M., Milošević, D., \& Mašović, S. (2012). Uporedna analiza uspešnosti savladavanja gradiva na tradicionalan način i putem Interneta. Inovacije u nastavi, 67-77.

Selimović, H., \& Tomić, R. (2011). Pedagogija I. Univerzitet u Travniku.

Song, H., Kalet, A., \& Plas, J. (2016). Interplay of prior knowledge, self-regulation and motivation in complex multimedia learning environments. Journal of Computer Assisted Learning, 32(1), 31-50. https://doi.org/10.1111/jcal.12117

Sukić, Ć. (2008). Multimedijalni sistemi. Ined-Grafomedia. 
Šikl, A. (2011). Modern educational technology: Effects of multimedia in teaching. Technology, Informatics and Education for learning and knowledge society (pp. 100-110). Technical Faculty Čačak.

Ulrich, K. (2003). Macromedia Flash Mx za Windows i Macintosh. CET Computer Equipment and Trade.

\section{Fadil Novalić}

Department of Computer Science

University of Novi Pazar

Dimitrija Tucovića bb, 36300 Novi Pazar, Serbia

fadilnovalic@uninp.edu.rs

Emruš Azizović

Department of Computer Science

University of Novi Pazar

Dimitrija Tucovića bb, 36300 Novi Pazar, Serbia

azizovic.emrus@gmail.com

\section{Faruk Selimović}

Department of Computer Science

University of Novi Pazar

Dimitrija Tucovića bb, 36300 Novi Pazar, Serbia

faruk@uninp.edu.rs

\section{Muzafer Saračević}

Department of Computer Science

University of Novi Pazar

Dimitrija Tucovića bb, 36300 Novi Pazar, Serbia

muzafers@uninp.edu.rs 


\section{Važnost primjene multimedijske aplikacije stvorene prema ADDIE modelu za poučavanje pisanja i čitanja slova}

\section{Sažetak}

U ovom radu ispituje se utjecaj multimedijskoga sadržaja na učenje čitanja $i$ pisanja slova. U svrhu istraživanja izrađena je multimedijska aplikacija za učenje čitanja i pisanja slova, prema ADDIE modelu instrukcijskoga dizajna. U radu je opisana aplikacija prikazom aplikacijskoga sučelja, opisom funkcija i dijelova koda. Istražene su tehničke mogućnosti korištenja multimedijske aplikacije kao i utjecaj njezine uporabe na svijest učenika i nastavnika o važnosti uvođenja multimedijskih nastavnih sadržaja. Glavno se istraživanje odnosi na uspjeh učenja čitanja i pisanja slova, a provedeno je usporedbom postignuća učenika na kraju školske godine u dvije osnovne škole.

Ključne riječi: aplikacija; e-učenje; obrazovanje; poboljšavanje nastave.

\section{Uvod}

E-učenje može se nazvati bilo kojim oblikom učenja koristeći moderne tehnologije. To obično uključuje korištenje računala. Prema definiciji Američke asocijacije ASTD (American Society for Trainers and Development) e-učenje je metodologija kojom se sadržaji poučavanja ili aktivnosti učenja isporučuju korištenjem elektroničkih tehnologija (Glušac, 2012).

Multimedija je kombinacija različitih formata sadržaja, najčešće teksta, slike, zvuka, animacije i videa. U literaturi utvrđena je sljedeća definicija: „Multimedija je kombinacija različitih medija: kombinacija teksta i slike (slika, ikona, animacija, film), kombinacija teksta i tona (glazba, govor) ili kombinacija teksta, slike i tona" (Sukić, 2008., str. 9).

Tempo tehnoloških promjena svakim danom postaje sve očitiji, s dramatičnim porastom računalne obrade, porastom mrežnoga opsega, objedinjavanjem medija i porastom komunikacije i interaktivnosti, stoga je lako pretpostaviti da su se i učionice potpuno promijenile. Promjene su, naravno, u tijeku, ali bilo bi pretjerano reći da je tehnologija radikalno promijenila učenje i poučavanje u većini obrazovnih ustanova. Primarna povezanost učitelja i učenika i ostvarenje poučavanja i učenja relativno je nepromijenjena stotinama godina. 
Multimedijsko e-učenje nalazi svoje mjesto u današnjem obrazovnom sadržaju. Ovaj oblik e-učenja i njegov utjecaj na uspjeh učenika predmet su mnogih udžbenika, stručnih i znanstvenih radova.

\section{Dosadašnja istraživanja}

U originalnom istraživačkom radu, autori (Song, Kalet i Plas, 2016), izostavljajući izravan utjecaj prethodnih znanja, ispitali su učinke samoregulacije i motivacije na jačanje sveobuhvatnoga razumijevanja kao osobine učenika u složenom multimedijskom okruženju za učenje. Upareni uzorak t-testa ukazuje na značajne razlike u znanju sudionika ispitivanja koje su prikazane prije ispitivanja i nakon ispitivanja: $\mathrm{t}(213)=20,29, \mathrm{p}<.001, \mathrm{~d}=1,84 \mathrm{u}$ deklarativnom znanju; $\mathrm{t}(213)=18,73, \mathrm{p}<.001$, $\mathrm{d}=1,56 \mathrm{u}$ pojmovnom znanju.

Multimedijski sadržaji posebno su prevladavajući u radu s učenicima nižih razreda osnovne škole. Mnogi udžbenici za učenike nižih razreda sadrže CD s multimedijskim sadržajem. To se najčešće događa s udžbenicima na stranim jezicima. Uloga i značaj primjene informacijskih tehnologija u obrazovnom radu s učenicima mlađe školske dobi je neosporna (Purić i Maričić, 2012).

Obrazovanje u suvremenom društvu zahtijeva inovaciju u poučavanju. Mogu se uvesti kroz različite primjene tehnike i informacijske tehnologije u obrazovni proces $u$ školama, uključujući i multimedijske sadržaje. Razvoj telekomunikacijske tehnologije i široka upotreba interneta omogućili su interaktivno učenje na daljinu zasnovano na sustavnom pristupu korištenjem multimedijskih elektroničkih izvora informacija, a studenti marljivo prate multimedijsku prezentaciju. Oni bolje pamte nastavne sadržaje i aktivnije sudjeluju u procesu učenja novih sadržaja. Brže usvajanje znanja omogućava učenicima da razmišljaju, analiziraju i zaključuju, da se više posvete učenju istraživanjem, otkrivanjem i rješavanjem problema. Uz formalno obrazovanje, studenti mogu dobiti i neformalno obrazovanje putem kućnih računala (Ostojin, 2012).

Autori (Lauc, Kišiček i Bago, 2014.) koristili su VARK osjetilni model: Visual (vizualni), Aural (auralni), Read/Write (tekstualni) i Kinesthetic (kinestetički), koji se odnosi na senzorni modalitet pojedinca. Prema rezultatima upitnika VARK, dva od tri učenika imaju multimodalne senzorne sklonosti i radije kombiniraju različite vrste multimedijskih izvora.

U svojim istraživanjima o pozitivnom utjecaju virtualnih okruženja na učenje, autori (Korićanin isur., 2014) ističu da je najzastupljenije virtualno okruženje koje se temelji na multimediji. Oni navode da je $55 \%$ učenika imalo iskustva s videoigrama, 27,5 \% $\mathrm{s}$ virtualnim svjetovima, $12,5 \% \mathrm{~s}$ virtualnom učionicom, dok je $5 \%$ imalo iskustva s virtualnim laboratorijima.

Mnogo je razloga koji podržavaju upotrebu multimedije u nastavi, a dva su najvažnija:

1. sposobnost prezentacije materijala na vrlo zanimljiv način, ponekad čak i kroz igru

2. slikovna prezentacija pojedinih elemenata građe djeci kroz slikovni, audio i videosadržaj i interakcija s multimedijskim obrazovnim softverom. 
Važno mjesto u razvoju e-učenja zauzima trenutak kada su multimedijski sustavi integrirani u sustave učenja. Uključivanje multimedijskih sustava povećalo je kvalitetu i učinak uporabe elektroničkih obrazovnih materijala. Najvažnija stvar koju donosi multimedija je sposobnost postizanja stvarne interaktivnosti, što se pokazalo ključnim čimbenikom u kvaliteti i učinkovitoj uporabi elektroničkih sadržaja u obrazovnom procesu (Sukić, 2008., str. 77).

Ako proučavamo učenje u kontekstu prikupljanja i obrade informacija usmjerenih na različita osjetila (vid, sluh, dodir i ostalo), možemo zaključiti da su prednosti informacijske tehnologije koja omogućava razmjenu informacija u mnogim formatima (tekst, zvuk, video) za proces učenja ogromne (LINKgroup, 2012., str. 72).

Stav nastavnika prema korištenju informacijske tehnologije u obrazovanju učenika nižih razreda istražen je u nekim stručnim radovima. Ispitujući mišljenja nastavnika o važnosti uporabe informacijske tehnologije i elemenata koji joj omogućuju uporabu u nastavi, dobili smo sljedeće rezultate: upotreba informacijske tehnologije u nastavi je, prema mišljenju najvećega broja učitelja (90,4 \%), značajna, a na to mišljenje ne utječu razlike s obzirom na godine radnoga iskustva i kvalifikacije učitelja (Purić i Maričić, 2012).

\section{Važnost primjene multimedijskih sadržaja u sustavima e-učenja}

Multimedijski sadržaji doprinose novom načinu učenja i poučavanja u kojem je fokus više na učeniku nego nastavnom sadržaju i nastavniku. Uvođenjem multimedije može se reći da se postižu sljedeći pozitivni rezultati u nastavnom procesu:

1. nastavni sadržaji postaju zanimljiviji, što znači i više motivacije učenika

2. teorijski elementi mogu se predstaviti slikovito, što omogućava bolje razumijevanje građe

3. testovi s povratnim informacijama mogu se integrirati u nastavni plan i program, omogućujući učenicima da samostalno testiraju svoje znanje i upute ih da se počnu natjecati sa sobom, poboljšavajući svoj uspjeh u svakom sljedećem pokušaju testiranja svojega znanja

4. proces učenja prilagođava se individualnim razlikama koje postoje kod učenika, pružajući tako svakom učeniku mogućnost da maksimizira učenje oslanjajući se na vlastite karakteristike koje predstavljaju njihove individualne prednosti.

Oblik multimedije s velikim potencijalom za upotrebu je digitalna animacija. Uključivanjem 3D grafike i stvaranjem uvjeta za interakciju korisnika s objektima na način koji simulira okolnosti iz stvarnoga života, stvaraju se uvjeti virtualne stvarnosti. Virtualna stvarnost ima veliki potencijal za primjenu u raznim profesionalnim područjima, poput arhitekture, poslovnoga modeliranja, urbanizma, medicine, zrakoplovstva itd. Napredak tehnologije povećao je mogućnost uporabe virtualne stvarnosti u obrazovanju (LINKgroup, 2012., str. 146). 
Novim generacijama učenika multimedija nije strana. Učenici 21. stoljeća razlikuju se od prethodnih generacija različitim načinom života i rada. Svakodnevno su okruženi multimedijom, protok informacija je brži nego prije, pa čak su djeca danas više informirana nego prije. Oni svakodnevno traže i koriste informacije. Učenici vješto koriste računalo, mobilni telefon, DVD i druge multimedije. Stoga njihove potrebe nadilaze razinu tradicionalnoga učenja (Shekel, 2011).

Uporaba multimedije u nastavi ima svoje teorijske osnove, a temelje se na sposobnosti učenika za bolje pamćenje gradiva koje ima vizualni učinak. Novije teorije učenja smatraju uvjetovanost procesa učenja vizualnom percepcijom, odnosno različitim kognitivnim sposobnostima ljudi. (LINKgroup, 2012, str. 39) U osnovi količina trajno zapamćene informacije ovisi o intenzitetu uključivanja osjetila u učenje. Znanstveno valjana teza je da se učenik prosječne sposobnosti može sjetiti $10 \%$ pročitanoga sadržaja, $20 \%$ sadržaja koji je čuo, $30 \%$ onoga što je vidio, $50 \%$ onoga što je istovremeno čuo i vidio, $70 \%$ onoga što može dramatizirati i pisati, a čak $90 \%$ onoga što sam dizajnira, kaže, shvati, učini (Schickl, 2011). U svojoj knjizi autor (Mayer, 2009, str. 60) kaže: „Kakva je uloga teorije učenja u oblikovanju multimedijskih nastavnih sadržaja? Odluke o dizajnu multimedijskih sadržaja uvijek se donose na temelju koncepta po kojem ljudi uče - čak i kad osnovna teorija učenja nije navedena. Dizajn multimedijskih poučnih sadržaja uvijek zahtijeva da dizajner sadržaja bude informiran o načinu na koji funkcionira ljudski um. Na primjer, kada multimedijska prezentacija čini da ekran bude preplavljen raznobojnim riječima i slikama koje trepere i kreću se - to odražava dizajnerovu koncepciju ljudskog učenja”.

Multimedija se može gledati na računalima, tabletima i mobilnim uređajima pomoću različitih softvera. Mrežni preglednici također pripadaju ovom softveru koji omogućava internetsku upotrebu multimedije u nastavi. Upotreba multimedije omogućena je standardima za oblikovanje i komprimiranje multimedijskih podataka. Oni se, između ostaloga, bave kvalitetom, veličinom i prenosivošću multimedijskih datoteka. Najčešći standardi slike su JPEG, MPEG-1 Layer III (MP3) audio i MPEG-2 i MPEG-4 video.

U svemu tome, djeci treba omogućiti korištenje informacijske tehnologije kako bi svladali osnovna znanja poput učenja čitanja i pisanja slova. Postojanje e-lekcija za učenje čitanja i pisanja slova dostupnih na internetu opravdava razmišljanje u tom smjeru. Ovakve lekcije čine učenje zanimljivijim, čak ga pretvaraju u neku vrstu igre, povećavajući motivaciju za učenje. Autorica (Glusac, 2012., str. 30) u svojoj knjizi navodi: „Djeca računalo unaprijed vide kao igračku, kao izvor zabave i spremna su $\mathrm{u}$ svakom trenutku klasični rad u razredu zamijeniti radom na računalu. Pri tome, nudeći im nastavne sadržaje temeljene na igrama, postižemo naše ciljeve učenja u mnogo bržem vremenu i uz bolja postignuća učenika. Motivacija je značajno veća te je, prema tome, poučavanje kvalitetnije i učinkovitije".

S obzirom na postojeću upotrebu multimedije u nižim razredima i učenikovu sklonost korištenju računala, smatrali smo važnim ispitati utjecaj multimedijske aplikacije na uspjeh učenika prvih razreda u učenju čitanja i pisanja slova. Napravili smo jednu takvu 
aplikaciju i testirali njezinu upotrebu u školi tijekom školske godine. U usporedbi s drugim aplikacijama za učenje pisma i učenja slova koje se mogu pronaći na internetu, našu aplikaciju nadopunjuje animacija ispisa slova, što je čini cjelovitijom. Istražili smo je li upotreba aplikacije dovela do promjene u stavu učenika i nastavnika prema korištenju multimedije u nastavi. Uključili smo i učenike prvog razreda druge osnovne škole koji nisu koristili multimedijske sadržaje u učenju slova. Prikupili smo ocjene po kojima su učitelji na kraju školske godine ocjenjivali učenike u čitanju i pisanju i napravili usporedbu uspješnosti.

\section{Multimedijska aplikacija za učenje čitanja i pisanja slova}

Obavezno je da učenici kada pođu u školu što prije svladaju čitanje i pisanje slova. Da bismo postigli ovaj cilj, u svrhu učenja čitanja i pisanja slova, izradili smo multimedijsku aplikaciju koja će pomoći u efikasnosti svladavanja gore navedenoga dijela gradiva. Za djecu koja uče slova, učinkovitost učenja je bolja ako je gradivo zanimljivo. U e-obrazovanju nastavni materijali mogu se predstaviti kao igra ili animacija. Treba uzeti u obzir pedagoške i psihološke karakteristike e-materijala.

\section{Psihološko-pedagoške osnove za kreiranje aplikacije}

Psihološki aspekti koji se tiču nastavnoga zadatka učenja čitanja i pisanja slova, kada se uzima u obzir i dob učenika, jesu samostalnost u učenju i motivacija.

Želja za samostalnošću u učenju određena je osobnošću učenika i vrstom gradiva. Postoje učenici koji lakše uče samostalno i rijetko traže pomoć odraslih, dok drugi više ili manje žele pomoć odraslih. U našem primjeru, nastavni materijal tahtijeva da učitelji ili roditelji usmjeravaju učenika tijekom učenja. Aplikacija koju smo kreirali sadrži sljedeće elemente koji mogu zamijeniti pomoć nastavnika:

1. prikaz svih slova

2. izgovor glasa koji je predstavljen slovom

3. izgovor riječi koje predstavljaju nazive objekata prikazanih na slici pokraj slova 4. ispisivanje slova.

Ovi elementi aplikaciji daju značajku sveobuhvatnosti.

Na motivaciju utječe nekoliko faktora, a ključni su:

1. učiniti materijal zanimljivim

2. smanjiti složenost nastavnih materijala

3. osposobiti učenike da se samostalno testiraju s povratnim informacijama

4. osposobiti učenike da ponovo uče i poboljšaju rezultate svojih testova

5. natjecati se s vršnjacima u nečemu što je svima zanimljivo.

Naša je aplikacija kreirana prema spomenutim čimbenicima. Sadrži grafičke elemente, animacije i zvuk koji djeci mogu biti vrlo zanimljivi s obzirom na njihovu dob. Aplikacija je jednostavna za korištenje. Sve što je potrebno pojavljuje se na sceni 
aplikacije, a gumbi koji zahtijevaju akciju učenika, predstavljeni su sličicama koje jasno pokazuju njihovu funkciju. Učenici se mogu testirati prepoznavanjem slova i čitanjem riječi, a zatim odmah čuti izgovor slova i riječi sadržanih u aplikaciji i na taj način provjeriti točnost izgovora. Osim toga, uvijek mogu preispitati slova u aplikaciji i slušati izgovore, utvrditi svoje znanje i ponovo se testirati. Dodatna motivacija za učenike te dobi je sudjelovanje u razgovorima o softveru koji svi koriste i uspjeh koji su postigli u učenju kroz njegovu upotrebu. Kao kad se natječu da bi prešli razinu računalnih igara koje svi igraju.

Pedagoški aspekti učenja čitanja i pisanja slova predstavljaju mjesto, vrijeme i tempo učenja. Ovo su aspekti koji se razmatraju u većini e-kolegija. Pedagoški aspekti e-nastave odnose se na fleksibilnost vremena i mjesta pohađanja. Kod e-nastave nije nužno da svi učenici u obrazovnom procesu budu na istom mjestu i u isto vrijeme (Saračević, Milošević i Mašović, 2012). Aplikacija za učenje pisma može se pokrenuti pomoću digitalnih uređaja, online ili offline, u vrijeme koje je povoljno za učenika. Učenik može odabrati brzinu učenja koja mu odgovara, a dodatna je korist to što je naviknut na računalo, u okruženju na koje je naviknut i kome mu je ugodno.

\section{Razvoj aplikacije prema ADDIE modelu instrukcijskoga dizajna}

Instrukcijski dizajn je proces u kojem se primjenjuju teorije učenja i pedagoške teorije, kao i različiti principi, tehnike i metode poučavanja, kako bi se što učinkovitije planirali i proizveli materijali za učenje, oblikovajući tako proces poučavanja i učenja u određenim predmetima i lekcijama (Anđelić, 2008). Povezuje teoriju i praksu u obrazovanom procesu. To je metodološki okvir za pronalaženje načina za što učinkovitiju integraciju inovacija u praksu.

U posljednje vrijeme obrazovne tehnologije mijenjaju način na koji poučavamo, posebno u visokom obrazovanju, a nastavni dizajn postaje sve popularniji čak i u programima koji se odvijaju u učionici. Tipičan nastavni postupak dizajna uključuje nekoliko koraka: planiranje, dizajn, proizvodnja, implementacija, evaluacija, revizija.

Koncept instrukcijskoga dizajna različito se shvaća, ali on u osnovi znači postupak kojim se planira, osmišljava, konstruira i razvija poučavanje, izvodi, organizira i kontrolira učenje, odnosno pronalazi se rješenja, optimalne strategije, putovi ili načini rada i učenja, odabir medija, modela i osmišljavanje nastavnih planova i programa na makrodidaktičkom planu koje učenik može pravilno steći u nastavi, učenju i radu na jednostavan, zanimljiv i isplativ način te da je novostečeno znanje trajno i primjenjivo u svakoj situaciji.

Upute za dizajn uključuju sljedeće:

1. kako najbolje organizirati sadržaj

2. kako prezentirati informacije na način koji će omogućiti najučinkovitije učenje

3. kako osmisliti i vrednovati aktivnosti kroz koje će učenici razviti dublje razumijevanje sadržaja (koristeći predstavljene informacije, primjenjujući koncepte i načela) 
- kako osmisliti i vrjednovati aktivnosti kroz koje će učenici razviti specifične vještine vezane uz njihovo područje učenja ili rada.

Za naše je istraživanje razvijen elektronički tečaj o učenju čitanja i pisanja pisama u obliku multimedijske aplikacije, prema ADDIE modelu instrukcijskoga dizajna. Ovaj model prolazi kroz pet faza: analiza (Analisys), dizajn (Design), razvoj (Development), implementacija (Implementation) i evaluacija (Evaluation).

Slika 1.

\section{Analiza}

Analiza potreba i prepoznavanje problema: Glavni problem u učenju čitanja i pisanja slova jest taj što je to prvi zadatak s kojim se učenici susreću kad krenu u školu, zbog čega je težak i zahtijeva stalnu pomoć u učenju. U multimedijskoj aplikaciji animacija i zvuk mogu učiniti učenje zanimljivijim i pružiti pomoć učenicima umjesto učitelja.

Analiza zadataka i uvjeta rada: Zadaća e-kolegija je omogućiti hibridnu vrstu predavanja u kojoj bi nastavnik osim tradicionalnoga načina poučavanja koristio multimedijske nastavne sadržaje koji bi učenicima omogućili samostalni rad kod kuće.

Analiza organizacijskih i tehničkih uvjeta za realizaciju tečaja: Nastava će se održavati u računalnoj učionici. U osnovnoj školi u kojoj je testirana upotreba multimedijske aplikacije postoji takva učionica. Računala su opremljena potrebnim softverom, a postoji i videoprojektor.

Ciljna grupa: Tečaj je namijenjen učenicima 1. razreda osnovnih škola u Srbiji.

Voditelj kolegija, supervizor: Moderator predmeta i supervizor je učitelj. On također obavlja evaluaciju.

Razdoblje završetka: Nastavno gradivo obuhvaćeno e-tečajem realizira se u nastavnom procesu školske godine 2018./2019.

Ciljevi i predviđeni ishodi: Ciljevi predmeta su:

1. osnovni cilj - da učenici uspješno svladaju čitanje i pisanje slova

2. sekundarni cilj - da učenici podignu razinu neovisnosti u učenju i razinu svijesti o korisnosti multimedijskih aplikacija u nastavi.

Po završetku tečaja od učenika se očekuje da će:

1. znati čitati i pisati sva slova materinskoga jezika

2. moći samostalno učiti uz pomoć računala

3. biti spremni samostalno pronalaziti nove obrazovne aplikacije i igre.

\section{Dizajn}

\section{Pregled tema}

Sve su teme e-kolegija povezane s lekcijama učenja pisma u sklopu predmeta Maternski jezik. 


\section{Opseg projekta}

Tečaj pokriva većinu kurikula jer lekcije za učenje slova čine glavni dio kurikula materinskoga jezika u prvom razredu.

Svrha: Aktivnosti su koncipirane i zamišljene tako da se nadograde na nastavnikovo predavanje u razredu.

Kontrolna točka: Posljednji sat školske godine na kojoj nastavnici ocjenjuju učeničku vještinu čitanja i pisanja.

\section{Materijali (sredstva)}

Nastavni materijal koji se koristi za oblikovanje e-kolegija je školski udžbenik. Dodatni materijali su audiosnimci izgovora glasova i riječi.

E-materijal za ovaj tečaj kreiran je u obliku Adobe Flash animacije. Učenici ga mogu pregledati na svom računalu iz uklonjive memorije (USB flash drive-a, CD-a itd.) i putem interneta na mrežnoj stranici.

\section{Zadaće predmeta}

Nastavna zadaća važan je dio nastave i određuje ih nastavni plan i program te se provode kroz nastavne aktivnosti. Sadržaj predmeta osmišljen je tako da doprinosi postizanju zadataka.

Nastava se izvodi pomoću tri nastavna zadatka: obrazovnoga, funkcionalnoga i odgojnoga zadatka. (Selimović i Tomić, 2011, str. 318)

Ovaj e-tečaj trebao bi ispuniti sljedeće obrazovne zadatke:

1. učenici će naučiti prepoznati sva slova

2. učenici će znati pisati slova

3. učenici će moći čitati riječi.

Funkcionalni zadatci ovoga e-kolegija su sljedeći:

1. učenici će moći čitati tekstove na svom maternjem jeziku

2. učenici će poboljšati svoje znanje i vještine o uporabi informatičkih tehnologija

3. učenici će ojačati inovativnu osobinu svoje ličnosti.

Ono što bi ovaj e-tečaj trebao postići u odgoju učenika je sljedeće:

1. potaknuti učenike da pronađu efikasnija rješenja za svladavanje gradiva

2. podići razinu neovisnosti u učenju.

\section{Sudionici}

U realizaciji tečaja sudjeluju učitelji i učenici svih šest razreda prvog razreda odabrane osnovne škole. Upravljanje tečajem obavlja nastavnik, koji je ujedno i moderator i jedan od kreatora tečaja. Također obavlja formativno ocjenjivanje učenika. Interna evaluacija rada izvršit će se analizom uspjeha učenika. Anketno ispitivanje, koje također provodi eksternu evaluaciju, provode autori studije.

VI. Veza

Sadržaj i aktivnosti tečaja usklađeni su s Nastavnim programom materinskoga jezika za prvi razred osnovne škole. 


\section{Razvoj}

U kreiranju aplikacije slijedili su se psihološki i pedagoški temelji, navedeni gore, i zahtjevi postavljeni u fazi analize i dizajna.

Aplikacija je kreirana u obliku animacije, a softver koji se koristio za njezinu izradu je Adobe Flash. Flash je softver za izradu objekata vektorske grafike i animiranje istih. Na jednom mjestu sakupio je sve potrebne alate: alate za crtanje grafike, alate za animiranje ovih grafika, alate za pravljenje elemenata sučelja i interaktivnost, kao i alate za stvaranje HTML-a potrebnoga za prikazivanje grafike, animacija i elemenata sučelja kao mrežnih stranica u čitaču. (Ulrich, 2003).

Aplikacija je osmišljena kao jedna scena u kojoj su sva slova prikazana u obliku povezanih tipki, a pojedinačne se animacije za svako slovo unose u scenu klikom na odgovarajući gumb. Gumbi su predstavljeni kao sličice. Svako slovo prikazuje jedno slovo, tiskano, veliko i malo, a pokraj njega sliku predmeta ili bića čije ime počinje tim slovom. Takva prezentacija dana je i u tiskanom udžbeniku. $U$ animaciji se nalazi sličica zvučnika pored svakog gumba. Klikom na njega čut će se izgovor pisma. Slova na sceni razvrstana su abecednim redom. Sve to pruža jednostavnost upotrebe za aplikaciju.

Slika 2.

Prilikom pokretanja animacije na scenu podrazumijevano se učitava vanjska animacija koja predstavlja slovo A. Za učitavanje vanjskih animacija koje predstavljaju druga slova na scenu, Adobe Flash koristi kôd ActionScript 2.0:

Kod 1. Programski kod ActionScript 2.0 za učitavanje vanjske animacije na scenu

Animiranje objekata na sceni obavljeno je pomoću vremenske trake. Na taj se način postiže učinak ispisa slova. Svako slovo, veliko i malo, ima svoj gumb sa sličicom olovke. Klikom na olovku započinje animacija koja pokazuje kako ispisati odgovarajuće slovo. Pored slova, nalazi se slika predmeta ili bića čije ime počinje tim slovom i riječ. Spomenuta riječ predstavlja ime predmeta i prikazuje se sličicom. Između natpisa postavljena je sličica zvučnika. Klikom na nju čut će se izgovor riječi, a klikom na sliku čut će se zvuk koji predmet ili biće emitira u stvarni svijet.

\section{Slika 3.}

$\mathrm{Na}$ ovaj način napravljena animacija može se izvršiti u Adobe Flash Playeru ili drugom videoplayeru, a može se umetnuti u mrežnu stranicu i koristiti na mreži.

\section{Implementacija}

E-tečaj učenja pisma provodit će se tijekom cijele školske godine u nastavi materinskoga jezika, na časopvima predviđenim za učenje slova. Učenici će samostalno koristiti aplikaciju u vrijeme i na mjestu po svom izboru, na računalu s CD-a ili s interneta.

\section{Evaluacija}

U e-kolegiju koji je predmet ovoga rada evaluacija se vrši analizom postignuća učenika u svladavanju zadatka učenja čitanja i pisanja. Evaluacija se proširuje istraživanjem 
podizanja svijesti učenika i nastavnika o korištenju multimedije u nastavi. Vanjsko vrednovanje, ocjene učenika i rezultati anketiranja predaju se školskom pedagogu i autorima istraživanja. U zajedničkim analizama naći će se nova rješena za poboljšanje nastavnoga procesa i mogućnosti uvođenja e-kolegija kao dopune tradicionalnom nastavnom procesu.

\section{Metodologija istraživanja}

Na početku škole svaki se učenik suočava sa zadatkom koji ih obvezuje na čitanje i pisanje na svojem jeziku. U našim školama postoje dvojezične nastave u školama, pa se neki učenici prvo susreću s latinicom, a neki s ćirilicom. Učenje slova zahtijeva intenzivnu pomoć učitelja u školi i odraslih ukućana. Korištenje informacijske tehnologije u učenju slova moglo bi djelomično zamijeniti pomoć odraslih. Osim toga, računalno potpomognuto učenje može biti zanimljivije učenicima od rada s ljudima, tako da bi se povećalo vrijeme u kojem učenici provode učenje. Ovdje ćemo predstaviti studiju utjecaja e-učenja, koja se temelji na korištenju multimedijske aplikacije, na uspjeh koji učenici postižu u učenju čitanja i pisanja slova.

\section{Problem, predmet i važnost istraživanja}

Proces učenja odvija se kroz čitanje, slušanje i promatranje. Sva tri ova procesa su neophodna. Za slušanje i gledanje čovjek je sposoban rođenjem, dok čitanje i pisanje mora učiti. Zato institucionalno obrazovanje svake osobe započinje učenjem slova materinskoga jezika. Razdoblje od jedne ili dvije godine u školama posvećeno je ovom zadatku. A uspjeh nije fakultativan, već je obvezan. Za učenje slova koriste se različiti alati: slikovnice, tiskani udžbenici, igračke i elektronički materijali na računalu ili internetu. To nas dovodi do problema istraživanja: može li upotreba multimedijskoga elektroničkog materijala statistički značajno poboljšati uspjeh učenika u učenju čitanja $i$ pisanja slova u usporedbi s uspjehom pri korištenju isključivo tiskanih školskih udžbenika. Problem je aktualan jer je čitanje neizbježan korak na početku školske ljestvice.

Kao predmet istraživanja uzeta je zainteresiranost učenika za korištenje multimedijske aplikacije u učenju i uvjetovanost uspjeha i načina učenja, tradicionalnog ili e-učenja.

Učenje pomoću računala ima svoje prednosti i mane. Mnogi su zabrinuti koliko vremena djeca provode za svojim računalom. Uvođenje e-učenja moglo bi biti značajno jer bi djeca dio vremena provela radeći za računalom radi učenja. Uz to, e-učenje ima neke prednosti u pogledu učinkovitijega učenja. Važnost ovoga istraživanja je ukazati na prednosti korištenja materijala za e-učenje koji su zanimljivi mlađim učenicima.

\section{Cilj i zadaće istraživanja}

Cilj studije je utvrditi može li upotreba multimedijskih aplikacija u učenju čitanja i pisanja slova dati bolje rezultate od tradicionalnoga učenja, kao i pridonijeti poboljšanju nastave maternjeg jezika za učenike prvih razreda uvođenjem kombinacije tradicionalnog učenja i e-obrazovanja. Ovaj se cilj proteže i u domenu psihološkoga djelovanja na učenike. Korištenjem multimedijske aplikacije trebali bi povećati svijest o korištenju 
računala u učenju na zanimljiv i koristan način, u odnosu na dominantnu ulogu igara u korištenju računala.

Na temelju navedenih ciljeva istraživanja definirani su sljedeće zadaće istraživanja:

1. osnovna zadaća istraživanja je pronaći najbolji način korištenja multimedije za uspješno učenje čitanja i pisanja slova

2. specifične istraživačke zadaće su:

a) podići svijest o korištenju multimedije u učenju i nastavi

b) istražiti mogućnosti korištenja multimedije u učenju s učenicima prvih razreda u školama i kod kuće.

\section{Istraživačke hipoteze}

Polazeći od utvrđenih istraživačkih ciljeva i zadaća postavljene su sljedeće istraživačke hipoteze:

1. opća hipoteza je da uporaba multimedijske aplikacije u učenju čitanja i pisanja pisama doprinosi postizanju boljeg uspjeha učenika u statistički značajnoj mjeri

2. specifične hipoteze:

a) razina svijesti o korištenju multimedije u učenju nije visoka i može se povećati korištenjem multimedijske aplikacije za učenje čitanja i pisanja slova

b) razina svijesti o korištenju multimedije u nastavi od strane nastavnika može se povećati pomoću multimedijske aplikacije za učenje čitanja i pisanja slova

c) postoje zadovoljavajući tehnički zahtjevi za korištenje multimedijske aplikacije za učenje čitanja i pisanja slova.

\section{Istraživačke varijable}

Sveukupni uspjeh primjene multimedijske aplikacije za učenje čitanja i pisanja slova odražava se kroz uspjeh koji učenici postižu u ispunjavanju zadataka. Zbog toga su neke varijable uvedene u ovo istraživanje.

Neovisna varijabla: Način održavanja nastave.

Zavisne varijable:

1. uspješno savladan zadatak od strane učenika na kraju školske godine

2. razina svijesti o uporabi multimedije u nastavi kod učenika

3. razina svijesti o upotrebi multimedije u nastavi od strane nastavnika.

Nastava može biti tradicionalna i hibridna (kombinacija tradicionalnoga učenja i e-učenja).

Zavisna varijabla kvantificira se za potrebe ovoga istraživanja s dvije stope uspjeha: zadovoljavajućom i nezadovoljavajućom. Varijable koje određuju razinu svijesti se ne skaliraju. Dovoljno je da se utvrdi da postoji pozitivna promjena.

\section{Metode, tehnike i instrumenti istraživanja}

Kao istraživačke metode korištene su teorijska analiza, eksperimentalna, povijesna i statistička metoda. Analiza teorija e-učenja dovodi do teorijskih osnova na kojima se 
istraživanje temelji. Eksperimentalna metoda opisuje postupak provođenja istraživanja na eksperimentalnim skupinama. Povijesnom metodom ispitivana je razina svijesti učenika i nastavnika o korištenju multimedije u nastavi prije i nakon korištenja naše aplikacije za učenje čitanja i pisanja slova. Statistička metoda korištena je za obradu rezultata dobivenih istraživanjem i za ispitivanje njihove statističke važnosti.

Istraživanje je provedeno pomoću tehnika intervjuiranja i procjene postignuća učenika. Ankete za studente, upitnik za nastavnike i ljestvica za ocjenjivanje sposobnosti čitanja $i$ pisanja učenika mogu se smatrati istraživačkim instrumentima.

\section{Populacija i uzorak istraživanja}

Populaciju istraživanja čine učenici prvih razreda osnovnih škola u Novom Pazaru. Uzorak je namjerno odabran, a čine ga učenici prvih razreda dviju škola. U jednoj školi su 152 učenika prvih razreda, a u drugoj 128.

Škola s više prvašića predstavljala je eksperimentalnu skupinu koja je koristila multimedijsku aplikaciju u nastavi (1. skupina), dok su drugu grupu činili prvašići iz škole u kojoj se nastava odvijala na tradicionalan način (2. skupina).

\section{Organizacija i tijek istraživanja}

Istraživanje je provedeno u školskoj godini 2018./2019. Početkom školske godine anketnim upitnikom prikupljeni su podatci o broju učenika prvih razreda koji imaju računalo i internetsku vezu kod kuće te o mogućnostima korištenja informacijske tehnologije u školskoj nastavi.

Početkom školske godine učitelji su distribuirali CD s aplikacijom ili URL gdje se aplikacija nalazi na internetu, u školi u kojoj se koristi multimedijska aplikacija. Predavali su lekcije o novim slovima u računalnoj učionici u školi, gdje su djeci pokazali aplikaciju pomoću videoprojektora. Na kraju školske godine nastavnici su testirali vještine učenika u čitanju i pisanju i ocijenili ih zadovoljavajućim ili nezadovoljavajućim. Rezultati o broju pozitivno i negativno ocijenjenih učenika za obje skupine dostavljeni su autorima istraživačkoga rada.

Anketa je provedena na početku i na kraju školske godine kako bi se istražila razina svijesti o korištenju multimedije u nastavi kod učenika i nastavnika.

\section{Statistička obrada podataka}

Analiza i interpretacija podataka odnosi se na rezultate dobivene eksperimentalnom metodom. Izračunane su mjere brojanja (broj učenika) i mjere odgovarajućega omjera (postotci). Rezultati dobiveni proračunom su prikazani kvantitativno. Upotrijebljen je t-test za provjeru statističke značajnosti razlika u postignućima učenika.

\section{Rezultati istraživanja}

Obrada rezultata istraživanja započela je hipotezama istraživanja. Rezultati će biti predstavljeni redoslijedom kojim su prikupljeni i obrađeni. 


\section{Udovoljavanje tehničkim zahtjevima za upotrebu multimedijske aplikacije}

Jedna specifična hipoteza glasi: da postoje zadovoljavajući tehnički uvjeti za korištenje multimedijske aplikacije za učenje čitanja i pisanja slova.

Pomoću upitnika pitali smo učenike grupe 1 imaju li računalo i internetsku vezu u domu. Od 152 učenika, 148 učenika posjeduje računalo (97 \%), a 139 je povezano s internetom (91\%).

Škola u kojoj provodimo eksperiment ima kabinet računala s internetskom vezom i videoprojektorom pa je učenicima moguće predstaviti multimedijsku aplikaciju. Moglo bi se reći da su tehnički uvjeti za korištenje multimedijske aplikacije za učenje čitanja i pisanja slova u potpunosti ispunjeni ako škola ima računalo i videoprojektor za predstavljanje aplikacije u razredu, a svaki učenik ima računalo kod kuće.

S obzirom da je mali postotak učenika koji nemaju računalo kod kuće, zaključujemo da naša hipoteza nije dokazana, ali da je visok postotak ispunjenja potrebnih tehničkih zahtjeva za korištenje multimedijske aplikacije za učenje čitanja i pisanja slova.

\section{Razina svijesti učenika o upotrebi multimedije u učenju}

Specifična hipoteza koju ćemo ovdje dokazati jest da razina svijesti o korištenju multimedije u učenju nije visoka i može se podići korištenjem multimedijske aplikacije za učenje čitanja i pisanja pisama.

Upitnik sadrži dva pitanja koja smo postavili učenicima:

1. Igrate li zvučne i animacijske igre na računalu ili internetu?
a) da
b) ne

2. Igrate li zabavne ili edukativne igre?
a) samo zabavne
b) samo edukativne
c) i jedne i druge.

Anketa s istim istraživanjem provedena je na početku i na kraju školske godine. Ispitani su učenici koji posjeduju računalo kod kuće. Rezultate ankete predstavili smo u tabličnom prikazu popisa kodova za podatke iz anketnoga upitnika.

Tablica 1.

Na početku školske godine 98 \% učenika igralo je računalne igre, a samo 2 \% učenika nikad nije igralo računalne igre. Nakon korištenja multimedijske aplikacije, na kraju školske godine svi su se učenici izjasnili kako igraju računalne igre.

Što se tiče vrste igara, na početku školske godine 119 učenika je izjavilo da su igrali samo zabavne igre (82 \%), 4 učenika igrala su samo obrazovne igre (3\%), a 22 učenika igrala su obje vrste igara (15\%). Krajem školske godine učenici su, nakon korištenja multimedijske aplikacije, u velikom postotku dali različite odgovore. Broj onih koji 
još uvijek igraju samo zabavne igre smanjio se na 83 (57 \%), broj učenika koji igraju samo edukativne igre je 6 (4\%), a broj onih koji igraju obje vrste igara znatno se povećava, 56 učenika (39\%).

Nakon korištenja multimedijske aplikacije za učenje čitanja i pisanja pisama, broj učenika koji igraju obrazovne računalne igre povećao se samo za $1 \%$, a broj onih koji igraju obje vrste igara povećan je za $24 \%$. To dokazuje našu hipotezu da razina svijesti o uporabi multimedije u učenju nije visoka i da se ona može podići korištenjem multimedijske aplikacije u učenju čitanja i pisanja slova.

\section{Razina svijesti nastavnika o upotrebi multimedije u učenju}

Sljedeća i posljednja specifična hipoteza koju ćemo ovdje dokazati jest da se razina svijesti o korištenju multimedije u nastavi od strane nastavnika može podići korištenjem multimedijske aplikacije u učenju čitanja i pisanja slova.

Upitnik sadrži samo jedno pitanje koje smo postavili učenicima:

Koristite li multimedijske računalne aplikacije sa svojim učenicima u nastavi?
a) nikad
b) rijetko
c) srednje
d) često.

Anketa s istim istraživanjem provedena je na početku i na kraju školske godine. Ispitano je svih 6 učitelja koji poučavaju učenike prvih razreda u školi koristeći multimedijsku aplikaciju za učenje čitanja i pisanja pisama. Rezultate ankete predstavili smo u tabličnom prikazu popisa kodova za podatke iz anketnoga upitnika.

\section{Tablica 2.}

Rezultati istraživanja pokazuju da je nakon korištenja multimedijske aplikacije za učenje čitanja i pisanja slova broj nastavnika koji koriste multimediju u nastavi srednje ili često povećao, a broj nastavnika koji to nikada ili rijetko rade smanjio. To dokazuje našu hipotezu da se razina svijesti o upotrebi multimedije u nastavi od strane nastavnika može podići korištenjem multimedijske aplikacije u učenju čitanja i pisanja slova.

\section{Uspjeh učenika u čitanju i pisanju slova}

Na kraju, dokazujemo opću hipotezu istraživanja: uporaba multimedijske aplikacije u učenju čitanja i pisanja slova doprinosi postizanju boljeg uspjeha učenika u statistički značajnoj mjeri.

Ovo je istraživanje provedeno na dvije grupe učenika. Jedna grupa koristila je našu multimedijsku aplikaciju kako bi naučila kako čitati i pisati slova. Druga grupa je slova učila na tradicionalan način. Na kraju školske godine dobili smo od učitelja izvješće o broju učenika iz obje skupine koji su u čitanju i pisanju pisama ocijenjeni pozitivno (zadovoljavajuće) ili negativno (nezadovoljavajuće). Rezultate ćemo prikazati u tablicama i grafovima te prikazati rezultate ispitivanja statističke značajnosti dobivenih razlika. 
Tablica 3.

Grafikon 1.

Vidimo da je 97 \% učenika pozitivno ocijenjeno u grupi 1, a $89 \%$ u grupi 2. Ispitivanje statističke značajnosti dobivenih razlika provedeno je pomoću t-testa. Koristeći formule za statističku obradu podataka (Kundačina i Banđur, 2007), dobili smo t-vrijednost $\mathrm{t}=2,72$. Izračunana $\mathrm{t}$-vrijednost uspoređuje se s graničnim vrijednostima. Na temelju statističke tablice s graničnim vrijednostima, vidimo da je za uzorak između $100 \mathrm{i}$ 200 ispitanika, granična vrijednost 1,98 na razini značajnosti od 0,05 i 2,63 na razini značajnosti od 0,01.

Rezultirajuća t-vrijednost viša je od granične vrijednosti na obje značajne razine, što znači da razlika dva postotka dobivena na uzorku nije slučajna. To dokazuje našu opću istraživačku hipotezu: uporaba multimedijske aplikacije u učenju čitanja i pisanja slova doprinosi postizanju boljeg uspjeha učenika u statistički značajnoj mjeri.

\section{Zaključci}

Upotreba multimedijskih nastavnih sadržaja ima svoju važnost, što dokazuje postojanje velikoga broja stručnih i znanstvenih radova o ovoj temi, kao i školskih udžbenika popraćenih diskovima s multimedijskim sadržajem. U literaturi se navode psihološki i pedagoški temelji upotrebe multimedije u nastavi, utjecaj multimedije na učenje ocjenjuje se pozitivnim, a današnje generacije učenika okarakterizirane su kao oni koji su bliski informacijskoj tehnologiji.

S obzirom na važnost ovladavanja čitanjem i pisanjem slova na početku škole te računajući na mogućnosti multimedijskoga nastavnog sadržaja, napravili smo multimedijsku aplikaciju za učenje čitanja i pisanja slova. Aplikacija je kreirana kao animacija, s umetnutim zvukom. Pruža pregled slova koja se koriste u južnoslavenskim jezicima, izgovor i pisanje, prikazuje predmete čije ime počinje određenim slovom i izgovor riječi predstavljenih tim imenima. Psihološki i pedagoški temelji spomenutoga nastavnog materijala uzeti su u obzir prilikom izrade aplikacije. Za izradu aplikacije korišten je instrukcijski dizajn, naime njegov ADDIE model. Kroz pet faza ovoga modela planiran je, detaljno osmišljen i implementiran elektronički tečaj o učenju čitanja i pisanja slova, temeljen na uporabi multimedijske aplikacije.

Istraživanje o važnosti primjene multimedijske aplikacije izrađene prema ADDIE modelu nastavnoga dizajna u učenju čitanja i pisanja slova provedeno je u skladu s već opisanom metodologijom i pokazalo je da je u ovom slučaju ona funkcionalna. Na temelju prikazanih rezultata istraživanja možemo izvesti sljedeće zaključke:

1. uporaba multimedijskih aplikacija u nastavi za učenike mlađe školske dobi ima pozitivan učinak na svijest učenika o svrsi upotrebe multimedijskih sadržaja na računalu

2. ostvaruje se utjecaj na učitelje u smislu poticanja učenika da koriste multimediju u svom učenju, a ne samo za zabavu 
3. uporaba multimedije u nastavi, kao i općenita primjena informacijske tehnologije, ne zahtijevaju velike, neizvodljive tehničke uvjete

4. uporaba multimedijskih aplikacija u nastavi za učenike mlađe školske dobi pomaže u boljem napretku usvajanja gradiva.

Očekivani i postignuti rezultati korištenja multimedijske aplikacije za učenje čitanja i pisanja slova su:

1. naučiti nove mogućnosti informacijske tehnologije

2. učenici postižu veći stupanj neovisnosti u učenju

3. nastavnici su više uključeni u poučavanje inovacijama.

Moderne škole trebale bi razumjeti neizbježnost inovacija u poučavanju mlađih učenika koristeći se informacijskom tehnologijom, posebno multimedijom, što može učiniti nastavne sadržaje zanimljivim. Ova vrsta materijala mogla bi se kreirati za velik broj tema i predmeta i distribuirati s udžbenicima, što dosad nije nepoznato, ali se uglavnom koristi za učenje stranih jezika. 